\title{
Factors That Affect The Masinical Productivity In The Indonesian Railway Industry
}

\author{
Mochamad Soelton \\ School of Economics and Management, Mercu Buana University, Indonesia \\ Nicko Alexander Visano \\ School of Economics and Management, Mercu Buana University, Indonesia \\ Irfan Noviandy Aulia \\ School of Economics and Management, Mercu Buana University, Indonesia
}

Fatchur Rohman

School of Economics and Management, Brawijaya University, Indonesia

Yudha B. Abadi

School of Economics and Management, Politeknik Sahid, Indonesia

Delfi Adelia

School of Economics and Management, Mercu Buana University, Indonesia

\begin{abstract}
This research aims to examine and analyze the effect of stress, psyches environment and self-efficacy on employee productivity with burnout as an intervening variable for employees of The Indonesia Railway Industry. The method used in this research is descriptive method. The object of this research is 43 employees of The Indonesia Railway Industry. The approach used in this research is the Component or Variance Based Structural Equation Model with the Smart-PLS analysis tool. The result showed stress that has positive and significant effect on burnout of The Indonesia Railway Industry. Psyches environment that has a negative and significant effect on burnout of The Indonesia Railway Industry. Self-efficacy that has a negative and significant effect on burnout of The Indonesia Railway Industry. Stress that has a negative and significant on productivity of The Indonesia Railway Industry. Psyches environment that has a positive and significant on productivity of The Indonesia Railway Industry. Self-efficacy that has positive and significant on productivity of The Indonesia Railway Industry. Burnout that has negative and significant effect on productivity of The Indonesia Railway Industry.
\end{abstract}

Keyword: Stress, Psyches Environment, Self Efficacy, Burnout, Productivity 
Soelton, M., Visano, N. A., Aulia, I. N., Rohman. F., Abadi. Y. B., \& Adelia, D. (2020) Factors That Affect The Masinical Productivity In The Indonesian Railway Industry. Archives of Business Research, 8(5). 49-62.

\section{INTRODUCTION}

Human resources are a priority for an organization or company, because the role of human resources as driving and determining the course of an organization. So that company activities can run well, it requires employees who have high knowledge and skills. Thus the task of human resource management is to manage, develop and choose good human resources, so that human resources can be a good contribution to the progress of the company. According to Stoner (2013), human resource management is an ongoing procedure that aims to supply an organization or company with the right people to be placed in the right position and the position when the organization needs it.

Productivity is a very important factor in the success of a business. Productivity contains two main concepts, namely efficiency and effectiveness. Efficiency measures the level of resources, both human, financial, and natural needed to meet the desired level of service, the effectiveness of measuring the results of service quality achieved (George J. Washin, 1997). Labor productivity is one of the things that need to be considered in order to support the success. Employee productivity can be judged from what employees do in their work. Productivity can also be a reflection of a high work ethic. The higher productivity of employees in the company, the higher of earnings and profits of the company. Thus productivity can be represented by the income or profits to be earned individual labor. Labor productivity is affected by the consciousness of each individual (such as discipline, attitude and environment) level of education and training has been received as well as self-management capabilities. But in fact, the productivity of a company is also influenced by several other factors. With that a company needs to pay attention to factors that affect the productivity so that productivity is increasing and not decreasing. Most companies have experienced a decline of productivity making it difficult to achieve organizational goals. And one of these companies, namely The Indonesia Railway Industry. From the percentage yield productivity gains, in 2017 amounted to $91.60 \%$, but decreased in 2018 and 2019 with a percentage of $91.25 \%$ and $90.70 \%$. Of course for 3 years has decreased and does not reach the predetermined targets. And in 2018 drastically decreased enough, the decline occurred in the number of results achievement of the performance of employees at The Indonesia Railway Industry amounted to $90.70 \%$ and far from the targets set.

According to Soelton and Riyadhus (2018) stress must be seen from cases that occur in patients if excessive will cause employees in a depressed condition, because they are no longer able to handle tasks that are too heavy. stress of unsuccessful employees will hurt the company because of decreased productivity. According to Wirawan (2012), stress is an unexpected reaction that arises from an increase in environmental responses in a person. Soelton and Atnani, (2018, Jumadi Et al, (2018), Hafid and Prasetio (2017), Wahyuni et al (2014), Ardana in Faliza (2011) stated the fact that one reason emphasizes the need to question stress because it cannot work optimally so that it will give negative results to the research results or in other words the company cannot optimize the results. produced.

This also affects the psychic environment that affects work productivity, because the psychic environment can affect work performance, while those related to the psychic environment will influence the emergence of integration, understanding, and low motivation (Ramli and Soelton, 2018), (Jumadi et al, 2018). Increasing and decreasing environmental performance will increase worker productivity (Retno Widowati, 2016). According to Soelton, (2018), Claws (2012) 
compilation of a person's self-efficacy increases, their life satisfaction will increase, this can increase on psychological, subjective well-being and mental well-being for example in terms of improvement and also fulfilling tasks that must be done and completed. According to Octary (2007) someone who has higher self efficacy than they can handle events and problems effectively. The higher self efficacy owned by employees, the more he produces high work productivity (Lukman, 2016). If it is related to the addition of work, there is no need for very good physical and physical conditions to cause fatigue (Soelton et al. 2019). According to Nurhayati (2017), Soelton et al (2018), Rahmawati and Amir (2013) boredom conditions will also have an impact on decreasing work performance and individual work performance in the work environment such as increasing oneself from work by increasing distance, more absences and cooperation, more absences and higher turnover than workers. other.

\section{LITERATURE REVIEW}

Meneze (2006) defined productivity as the employee's ability to produce work or goods and services according to the expected standards set by the employers, or beyond the expected standards. According to the International Labor Organization (ILO), work productivity is a scientific comparison between the amount produced and the amount of each source used during production.

Burnout is a psychological syndrome that arise from prolonged stress due to interpersonal problems at work (Maslach \& Leiter, 2016). Burnout is exhausted physically, emotionally, and mentally due to long-term involvement in situations full of emotional demands (Pines and Aronso in Nursalam, 2015). According to the National Safety Council (NSC) (in Maharani \& Triyoga, 2012) explains that burnout is the result of perceived stress on workloads common specific symptoms in burnout in the form of boredom, pessimism, lack of concentration, quality of work is not satisfactory, depression, decreased job satisfaction, absence from work, ill or suffering from an illness.

Job burnout refers to the state in which individuals experience physical and mental fatigue after working under heavy pressure (Maslach et al. 2001; Peng et al.2014). Such concept was introduced in 1974 by Freudenberger, who considered job burnout as a symptom of emotional exhaustion that was commonly observed among individuals working in helping professions (Freudenberger1974; Shihetal.2013). Maslach defined psychological syndrome as a result of a long-term experience of work and interpersonal burnout (Maslach and Jackson 1981; Pines and Maslach 1978). In general, job burnout is an extreme reaction that individuals experience when they cannot successfully cope with work pressure. This condition refers to an exhausted state of emotion, attitudes, and behavior that arises from a prolonged experience of stress.

While Robbins (2013), work stress is a dynamic condition in which an individual is faced with an opportunity, constraint, or demand related to what they want and the result is perceived as uncertain. According Soelton and Riyadhus (2018) stress should be seen from the case by case which occurred on the sufferer if the excess will cause employees under pressure, because no longer able to cope with a task too heavy. Stress experienced employees will hurt the company because the resulting productivity may decline. Malek (2010) stated that stress is an unpleasant emotional situation that an individual experience when requirements of a job are not counter 
Soelton, M., Visano, N. A., Aulia, I. N., Rohman. F., Abadi. Y. B., \& Adelia, D. (2020) Factors That Affect The Masinical Productivity In The Indonesian Railway Industry. Archives of Business Research, 8(5). 49-62.

balanced with his ability to cope with the situation. It is a well-known phenomenon that expresses itself differently in various work situations and affects the workers differently.

According Soelton (2018) the work environment is one of the factors that determine the productivity of the company. If psyches environment is bad it can cause burnout, emotional tension and low motivation. Sedarmayanti (2011) states that, generally speaking, the type of work environment is divided into two, namely the physical work environment and non-physical work environment. Sedarmayanti (2011) states that the non-physical work environment are all circumstances that occur relating to the employment relationship, either with superiors or with fellow colleagues or relations with subordinates. Bandura (1997) self-efficacy is the belief someone to be able to organize and carry out an action that is required to achieve a certain goal. Self-efficacy refers to the speculation and judgment of whether an individual is capable of completing an action (Cupertino et al. 2012; Kamen et al. 2013)

Santrock (2012) states that self-efficacy is the belief that one can master a situation and provide a favorable outcome. Meanwhile, according to Baron and Byrne (in Hapsari, 2016) defines selfefficacy as a person evaluation of the ability or competence to perform a task, achieve a goal, and overcome obstacles. According Trouillet (in Irfan \& Veronika, 2014) said that self-efficacy is considered a person that affects how a person faces the external situation.

\section{CONCEPTUAL FRAMEWORK}

According to Saunders et al. (2007), "A conceptual framework indicates how the researcher views the concept involved in a study, especially the relationship among concepts". It can guide research by providing an illustration of theoretical constructs and variables of interest. Designing a conceptual model begins with conducting a thorough review of the literature. Peer-reviewed journal articles, books/monographs, conference papers, theses/dissertations and other relevant references have investigated for conducting this research. Therefore, researchers have developed a conceptual framework based on the causes and influencing factors of productivity.

Based on the previous findings of theoretical literature and the need for more studies, below is the proposed research framework for this study.

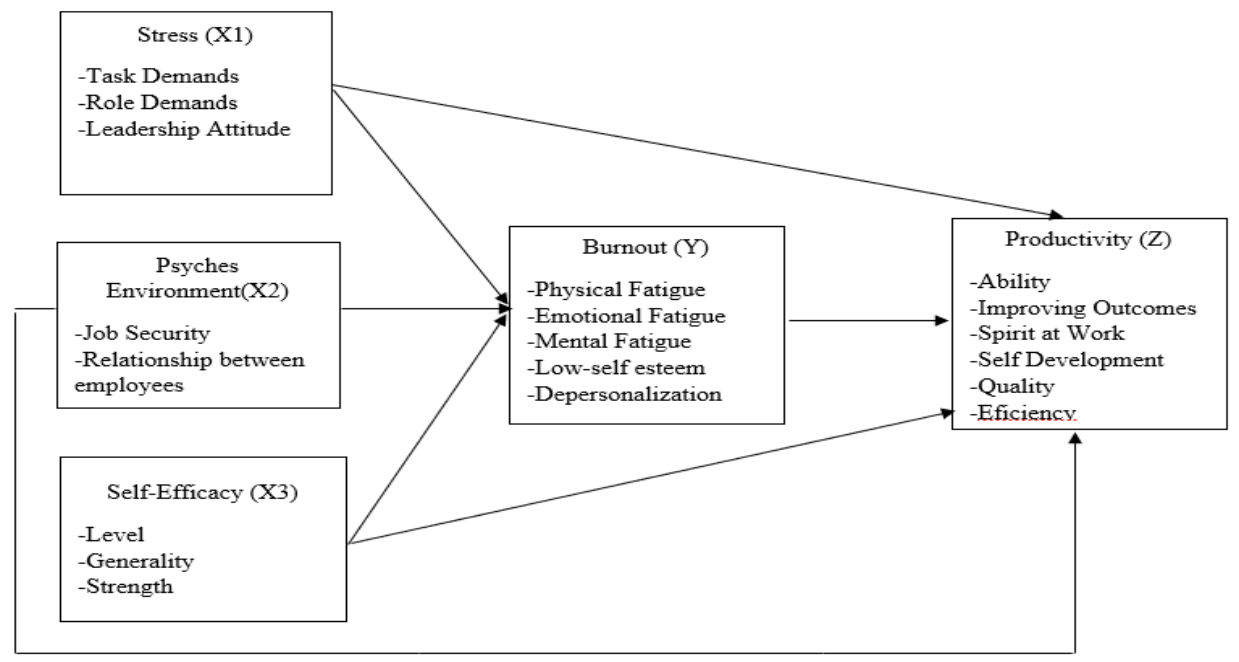

Fig. 1. Conceptual Framework 


\section{Research Design}

\section{RESEARCH METHODOLOGY}

In this study, the study design used is classified as causal research. Causal research design is useful to analyze the relationships between the variables with other variables. In this study, researchers interested in examining the independent variables are stress, psyches environment, self-efficacy to productivity as the dependent variable with Burnout as an intervening variable in The Indonesia Railway Industry.

\section{Data Collection Instrument}

The instrument used for data collection was a questionnaire submitted to the employees. Questionnaires were distributed to 43 respondent employees of The Indonesia Railway Industry. The population in this study is a machinist The Indonesia Railway Industry at Manggarai totaling 398 employees consisting of 43. With determination of the samples used in this study using a type of saturated sample method. The sample in this study were 43 respondents with the status of employees of The Indonesia Railway Industry. Unit for the population of employees with a number of 43 employees, by providing questionnaires to employees or employees of The Indonesia Railway Industry. The analytical method used in this study is the Component or Variance Based Structural Equation Model in which the data processing using the program Partial Least Square (Smart-PLS) PLS 3.2.8 version. PLS (Partial Least Square) is the alternative models of covariance-based SEM.

\section{Validity and Test Reliability}

\section{RESULT}

Table 1. Results of Convergent Validity Testing

\begin{tabular}{|c|c|c|c|}
\hline Nariabel & Indicator & $\begin{array}{c}\text { Onuter } \\
\text { Loudiong }\end{array}$ & Information \\
\hline \multirow{9}{*}{ Stress } & SR1 & 0.914 & Valid \\
\hline & SK2 & 0.807 & Valid \\
\hline & SR3 & 0.878 & Valid \\
\hline & SR4 & 0.735 & Valid \\
\hline & SK5 & 0.837 & Valid \\
\hline & SK6 & 0.659 & Valid \\
\hline & SK 7 & 0.643 & Valid \\
\hline & SK8 & 0.714 & Valid \\
\hline & SK10 & 0.573 & Valid \\
\hline \multirow{4}{*}{$\begin{array}{c}\text { Psyches } \\
\text { Enxironment }\end{array}$} & PEI & 0.786 & Valid \\
\hline & PE2 & 0.907 & Valid \\
\hline & PE3 & 0.929 & Valid \\
\hline & PE4 & 0.863 & Valid \\
\hline \multirow{7}{*}{ Self-Efficacy } & SEI & 0.742 & Valid \\
\hline & SE2 & 0.824 & Valid \\
\hline & SE 4 & 0.809 & Valid \\
\hline & SE 5 & 0.853 & Valid \\
\hline & SE6 & 0.857 & Valid \\
\hline & SE7 & 0.807 & Valid \\
\hline & SES & 0.716 & Valid \\
\hline \multirow{10}{*}{ Bumout } & $\mathrm{BO} 1$ & 0.854 & Valid \\
\hline & $\mathrm{BO}_{2}$ & 0.807 & Valid \\
\hline & $\mathrm{BO3}$ & 0.848 & Valid \\
\hline & BO4 & 0.813 & Valid \\
\hline & BO5 & 0.747 & Valid \\
\hline & BO6 & 0.872 & Valid \\
\hline & $\mathrm{BO} 7$ & 0.865 & Valid \\
\hline & BO9 & 0.788 & Valid \\
\hline & $\mathrm{BO}$ & 0.582 & Valid \\
\hline & BOII & 0.576 & Valid \\
\hline \multirow{11}{*}{ Productivity } & P1 & 0.671 & Valid \\
\hline & $p_{2}$ & 0.618 & Valid \\
\hline & p3 & 0.893 & Valid \\
\hline & P4 & 0.859 & Valid \\
\hline & P5 & 0.862 & Valid \\
\hline & P6 & 0.857 & Valid \\
\hline & P7 & 0.920 & Valid \\
\hline & P8 & 0.925 & Valid \\
\hline & p9 & 0.947 & Valid \\
\hline & P10 & 0.789 & Valid \\
\hline & P11 & 0.574 & Valid \\
\hline
\end{tabular}


Soelton, M., Visano, N. A., Aulia, I. N., Rohman. F., Abadi. Y. B., \& Adelia, D. (2020) Factors That Affect The Masinical Productivity In The Indonesian Railway Industry. Archives of Business Research, 8(5). 49-62.

Table 1 shows that all indicators have met the convergent validity, because it has a loading factor above 0.5 and thus all the indicators to measure the construct of the study was valid. If all indicators have loading factor above 0.5 then the proposed measurement model has the potential for further testing.

Table 2. Composite Reliability Testing Results

\begin{tabular}{|c|c|c|c|}
\hline Variables & $\begin{array}{c}\text { Cronbach } \\
\text { Alpha's }\end{array}$ & $\begin{array}{c}\text { Composite } \\
\text { Reliability }\end{array}$ & Information \\
\hline Burnout & 0928 & 0939 & Reliable \\
\hline Productivity & 0948 & 0957 & Reliable \\
\hline $\begin{array}{c}\text { Psyches } \\
\text { Environment }\end{array}$ & 0896 & 0927 & Reliable \\
\hline Self-Efficacy & 0908 & 0928 & Reliable \\
\hline Stress & 0904 & 0923 & Reliable \\
\hline
\end{tabular}

Table 2 show that the results of testing composite reliability and Cronbach's alpha show satisfactory values, because all latent variables have composite reliability and Cronbach's alpha values $\geq 0.70$. This means that all latent variables are said to be reliable.

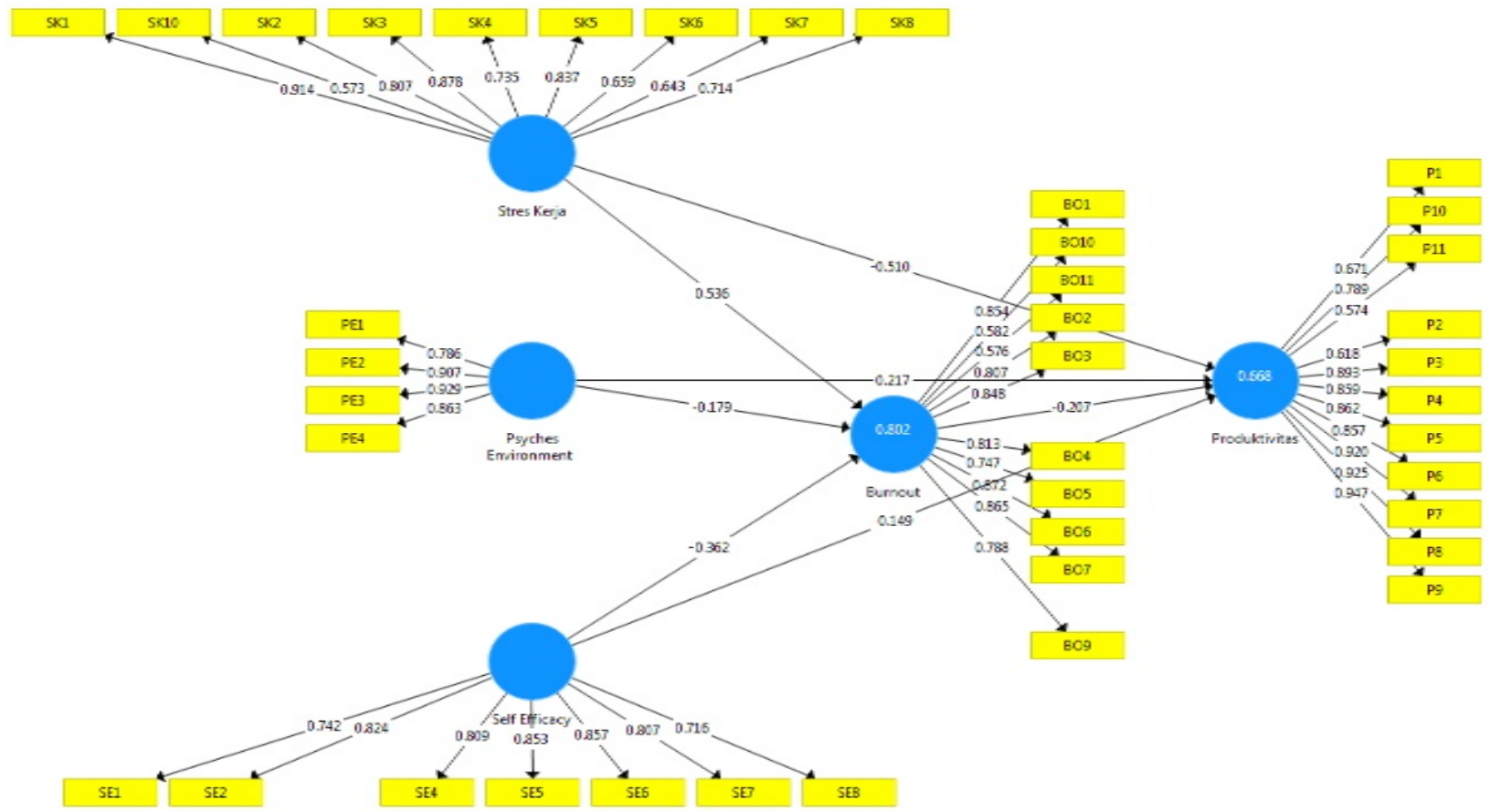

Figure 2: The Correlation of Variables

Source: From data processing (2019)

\section{Hypothesis Test}

As a basis for making hypotheses by comparing the amount of $t$-table with $t$-test at alpha of 0.05 $(5 \%)=1.96$. If the $\mathrm{t}$-table is less than alpha 1.96, then the hypothesis is not accepted or rejected, and vice versa if the t-table> 1.96, then the hypothesis is accepted or a significant difference between the two variables. 
Table 3. Results of Hypothesis Testing

\begin{tabular}{lccccc}
\hline & $\begin{array}{c}\text { Original } \\
\text { Sample }\end{array}$ & $\begin{array}{c}\text { Standard } \\
\text { Deviation }\end{array}$ & $\begin{array}{c}T \text { - } \\
\text { Statistics }\end{array}$ & $\begin{array}{c}\boldsymbol{P} \\
\text { Values }\end{array}$ & Keterangan \\
\hline $\begin{array}{l}\text { Stress } \rightarrow \\
\text { Burnout }\end{array}$ & 0.536 & 0.129 & 4.921 & 0.000 & $\begin{array}{c}\text { Positive - } \\
\text { Significant }\end{array}$ \\
$\begin{array}{l}\text { Psyches } \\
\text { Environment } \rightarrow \\
\text { Burnout }\end{array}$ & -0.179 & 0.113 & 2.095 & 0.042 & $\begin{array}{c}\text { Negative - } \\
\text { Significant }\end{array}$ \\
$\begin{array}{l}\text { Self-Efficacy } \rightarrow \\
\text { Burnout }\end{array}$ & -0.362 & 0.152 & 2.381 & 0.018 & $\begin{array}{l}\text { Negative - } \\
\text { Significant }\end{array}$ \\
$\begin{array}{l}\text { Stress } \rightarrow \\
\text { Productivity }\end{array}$ & -0.510 & 0.209 & 2.924 & 0.004 & $\begin{array}{l}\text { Negative - } \\
\text { Significant }\end{array}$ \\
$\begin{array}{l}\text { Psyches } \\
\text { Environment } \rightarrow \\
\text { Productivity }\end{array}$ & 0.217 & 0.121 & 2.792 & 0.034 & $\begin{array}{c}\text { Positive - } \\
\text { Significant }\end{array}$ \\
$\begin{array}{l}\text { Self-Efficacy } \rightarrow \\
\text { Productivity }\end{array}$ & 0.149 & 0.161 & 2.026 & 0.001 & $\begin{array}{c}\text { Positive - } \\
\text { Significant }\end{array}$ \\
$\begin{array}{l}\text { Burnout } \rightarrow \\
\text { Productivity }\end{array}$ & -0.207 & 0.211 & 2.183 & 0.006 & $\begin{array}{l}\text { Negative - } \\
\text { Significant }\end{array}$ \\
\hline $\begin{array}{l}\text { Source: From data processing (2019) } \\
\text { pring }\end{array}$ & & & &
\end{tabular}

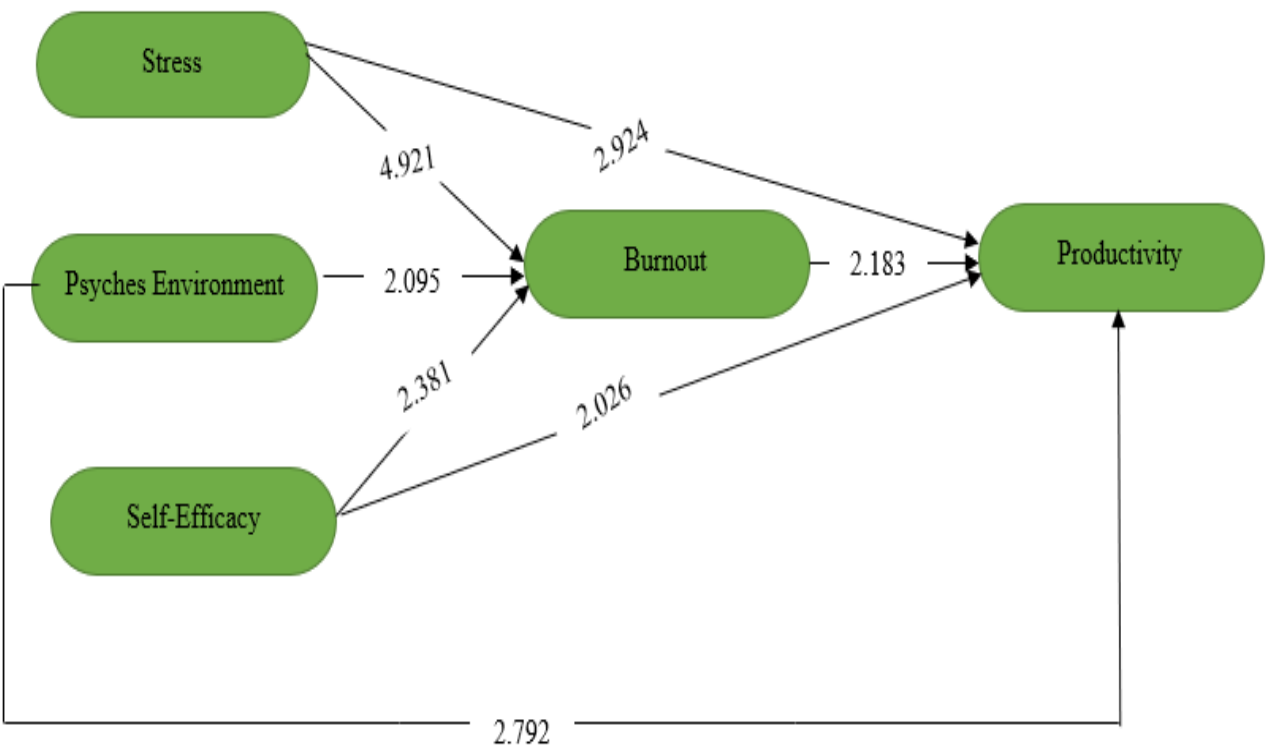

Figure 3: The Testing Result

Source: From data Processing (2019)

\section{Effect of Stress on Burnout}

Based on hypothesis testing in this study showed T-statistic values for 4921, the value of the original sample0536And the $P$ value Values of 0000 , Value T-statistic greater than the value of the T-table 1.96, the value of the original sample showing a positive value, and at a $P$ value less than 0.05 Values show, these results suggest that job stress positive and significant effect on the burnout. This study shows that stress has a significant relationship to burnout, which may mean that the stress effect on burnout. According YU et.al stress experienced by the individual in the long term can lead to burnout. This means that the high level of perceived job stress, the higher the perceived 
Soelton, M., Visano, N. A., Aulia, I. N., Rohman. F., Abadi. Y. B., \& Adelia, D. (2020) Factors That Affect The Masinical Productivity In The Indonesian Railway Industry. Archives of Business Research, 8(5). 49-62.

levels of burnout, as well as also the lower the perceived work stress, the lower the level of perceived burnout. According to Yu et al. (2015) that stress influence positively and significantly related to burnout. According Khamisa et al. (2015) showed that job stress positive effect on burnout.

\section{Effect of Psyches Environment on Burnout}

Based on hypothesis testing in this study showed T-statistic values for 2095, the value of the original sample -0179And the P value Values of 0042, Value T-statistic greater than the value of the T-table 1.96, the value of the original sample is negative, and at a P value less than 0.05 Values show, these results suggest that psyches environment a significant negative effect on burnout.

This study showed the better the psyches of environment the lower the burnout symptoms exhibited by employees and environment conditions such low psyches were not good communication between colleagues, superiors or subordinates it will support the occurrence of burnout. In line with research. It is also in line with research conducted Nantsupawat et.al. (2016) states that the psyches of environment negatively affect burnout.

\section{Effect of Self Efficacy on Burnout}

Based on hypothesis testing in this study showed T-statistic values for 2381, the value of the original sample -0362And the P value Values of 0018, Value T-statistic greater than the value of the T-table 1.96, the value of the original sample is negative, and at a P value less than 0.05 Values show, these results suggest that self-efficacy a significant negative effect on burnout.

This research proves that the higher self-efficacy a person has, the lower the chance of burnout. And the lower the self-efficacy a person has, the higher the level of burnout. According Lauerman and Konig (2016) states that self-efficacy significantly and negatively related to burnout. And according Skaalvik and Skaalvik (2010) showed that self-efficacy significantly and negatively related to burnout.

\section{Effect of Stress on Productivity}

Based on hypothesis testing in this study showed T-statistic values for 2924, the value of the original sample -0510And the P value Values of 0004, Value T-statistic greater than the value of the $\mathrm{T}$-table 1.96, the value of the original sample is negative, and at a $\mathrm{P}$ value less than 0.05 Values show, these results suggest that job stress a significant negative effect on productivity,

Work stress is distress experienced by employees in the face of job. This study shows that if the level of employee stress is high, then it will decrease employee productivity levels. Results of research conducted Saefullah et al. (2017) showed that stress has a negative and significant relationship to productivity. And in line with research conducted Saranani (2013) showed that stress has a negative and significant relationship to productivity. According to Ehsan and Ali (2019) stress a significant negative effect on productivity.

\section{Effect of Psyches Environment on Productivity}

Based on hypothesis testing in this study showed T-statistic values for 2792, the value of the original sample0217And the P value Values of 0034, Value T-statistic greater than the value of the T-table 1.96, the value of the original sample showing a positive value, and at a $\mathrm{P}$ value less than 
0.05 Values show, these results suggest that psyches environment positive and significant impact on the productivity.

In this company proves that the psyches of environment impact on productivity. This means that the good state of the psyches of environment, the higher the productivity of a given employee. In line with research conducted Sinaga and Ibrahim (2016) states that there is a positive and significant relationship psyches environment to work productivity. And in line with the research conducted Retno Widowati (2016) that there is a positive and significant relationship between the psyches of environment on productivity.

\section{Effect of Self Efficacy on Productivity}

Based on hypothesis testing in this study showed T-statistic values for 2026, the value of the original sample0149And the P value Values of 0001, Value T-statistic greater than the value of the T-table 1.96, the value of the original sample showing a positive value, and at a $\mathrm{P}$ value less than 0.05 Values show, these results suggest that self-efficacy positive and significant impact on the productivity

Self-efficacy is their belief in the ability to perform actions that will produce the intended impact. Self-efficacy is crucial owned by employees, because many employees have the ability even if it does not have confidence in himself the task not be resolved. This means that the higher one's own self efficacy, the higher the productivity of its work and vice versa. Results of research conducted Judge (2016) showed that self-efficacy and significant positive effect on productivity.

\section{Effect of Burnout on Productivity}

Based on hypothesis testing in this study showed T-statistic values for 2183, the value of the original sample -0207And the P value Values of 0006, Value T-statistic greater than the value of the T-table 1.96, the value of the original sample is negative, and the value of $p$ values less than 0.05 indicate, these results suggest that burnout a significant negative effect on productivity.

Burnout is a psychological process that is generated by the stress of work is not liberated and produces emotional fatigue, personality changes and feelings. The existence of burnout will affect the level of productivity that employees and will reduce the productivity level. In line with results of research conducted Judge (2016) states that burnout significant negative effect on productivity. And in line with the results of research conducted Woo et.al (2017) which state that burnout significant negative effect on productivity.

\section{Conclusion}

\section{CONCLUSIONS AND SUGGESTION}

This study tries to analyze the variables associated with work stress, psyches environment, selfefficacy, burnout, and productivity, Results of this study was obtained from research on the employees of The Indonesia Railway Industry. From the results of the calculations in this study, it can be concluded as follows:

1. Stress has a significant positive effect on burnout on The Indonesia Railway Industry employees. This means that the higher the level of work stress felt by someone, the higher the level of burnout that exists. 
Soelton, M., Visano, N. A., Aulia, I. N., Rohman. F., Abadi. Y. B., \& Adelia, D. (2020) Factors That Affect The Masinical Productivity In The Indonesian Railway Industry. Archives of Business Research, 8(5). 49-62.

2. Psyches environment has a significant negative effect on burnout on The Indonesia Railway Industry employees. This means that the better the employee's perception of the psychological work environment, the lower the burnout symptoms exhibited by the employee.

3. Self efficacy has a significant negative effect on burnout on The Indonesia Railway Industry employees. This means that the higher the self-efficacy a person has, the lower the chance of burnout.

4. Job stress has a significant negative effect on productivity in The Indonesia Railway Industry employees. This means that the lower the level of stress a person feels at work, the higher the level of productivity a person will do in his work.

5. Psyches environment has a significant positive effect on productivity in The Indonesia Railway Industry employees. This means that the better the psychological work environment of an employee, the higher the work productivity he will provide.

6. Self efficacy has a significant positive effect on productivity in The Indonesia Railway Industry employees. This means that the higher the confidence in him (self-efficacy) in completing his task, the higher the level of productivity of his performance.

7. Burnout has a significant negative effect on productivity in The Indonesia Railway Industry employees. This means that if an employee's burnout level is low, the higher productivity the employee will provide in carrying out their duties.

\section{Suggestion}

Based on the conclusion, it can put forward some suggestions into consideration for The Indonesia Railway Industry or for further research:

\section{Suggestions for The Indonesia Railway Industry}

1. Leaders must provide clear information to the tasks assigned to the employee, to avoid mistakes and pressure at work.

2. The company should provide a career path, it can encourage employee motivation to work.

3. The company must provide a positive side to the tasks assigned to employees, so that employees can always look at the positive side.

4. Companies should allow time for quality time on the employees, such as the gathering.

5. The company should control every job given to employees, in order to maintain the timeliness in settlement.

\section{Suggestions for Further Research}

Suggestions for further research, which will conduct research in the same field and using this paper as a reference, it would need to be reviewed because it is possible there are statements that have not been appropriate, because as the author feels there are still many shortcomings and limitations in completing this research.

\section{References}

1. Alwisol. (2009). Psikologi Kepribadian. Malang: UMM Press.

2. Ardika, Sulaeman. (2014). Pengaruh Upah dan Pengalaman Kerja Terhadap Produktivitas Karyawan Kerajinan Ukiran Kabupaten Subang. Trikonomika, 13 (1), 1 - 15.

3. Bandura, Albert. (2002). Self Efficacy: The Exercise of Control. New York: W. H Freeman \& Company. 
Archives of Business Research (ABR)

Vol.8, Issue 5, May-2020

4. Chou, L.I., Yi-Li, C., \& Hu, S. (2014). Job Stress and Burnout in Hospital Employees. ResearchesGate, 1-7. DOI: 10.1136/ bmjopen-2013-004185.

5. Danang, Sunyoto. (2012). Manajemen Sumber Daya Manusia. Jakarta: PT Buku Seru.

6. Davis, K. \& Newstrom, J.W (1996). Perilaku dalam Organisasi. Jakarta: Erlangga.

7. Dessler. (2013). Manajemen Sumber Daya Manusia Human Resources. Jakarta: Prenhalindo.

8. Ehsan, M. \& Ali, K. (2019). The Impact of Work Stress on Employee Productivity Based in The Banking Sector of Faisalabad, Pakistan. International Journal of Innovation and Economics Developments, 4 (6), 32-50. DOI: 10.18775/ijied.1849-7551-7020.2015.46.2003.

9. Feist, J. \& Gregory, J. F. (2010). Teori Kepribadian. Jakarta: Penerbit Salemba Humanika.

10. Guion, R. (2011). Assesment, Measurement, and Prediction for Personal Decisions. New York: Routledge

11. Hakim, Lukman (2016). Produktivitas Kerja ditinjau dari Burnout dan Self efficacy. Jurnal Psikoislamika, 13 (2), 23-38.

12. Hartawati, D., \& Mariyanti, S. (2014). Hubungan Antara Self Efficacy dengan Burnout pada Pengajar Taman Kanak-kanak Sekolah "X" di Jakarta. Jurnal Psikologi, 12 (2), 54-60.

13. Hasibuan, Malayu S.P. (2016). Manajemen Sumber Daya Manusia. Edisi Revisi, Jakarta: Bumi Perkasa.

14. Idris, M.M. (2016). Biaya dan Produktivitas Tree Length Logging di Hutan Alam Produksi. Jurnal Penelitian Hasil Hutan, 30 (4), 269-278.

15. Idrus, S. (2014). Pengaruh Self Efficacy Terhadap Burnout Pramuwisata di Nusa Tenggara Barat. Media Bina Ilmiah, 8 (6).

16. Irawati, A. (2012). Pengaruh Beban Kerja Terhadap Produktivitas Karyawan Sentra Kredit Konsumen. Jurnal Sekolah Manajemen Telekomunikasi Media.

17. Imaniar, R.R.L., \& Sularso, A.R. (2016). Pengaruh Burnout Terhadap Kecerdasan Emosional, Self-Efficacy, dan Kinerja Dokter Muda di Rumah Sakit dr. Soebandi. Jurnal MAKSIPRENEUR, 5 (2), 46-56.

18. Jankome, P.K., \& Ritacco, G. (2013). The Impact of Stress and Burnout on Employees Productivity at Boswana Power Corporation. International Journal of Innovation and Economics Development, 4 (6), 32-50.

19. Ravianto, J. (2013). Produktivitas Dan Pengukuran. Jakarta: Binama Aksara.

20. Kartono. (2001). Panthologi Sosial 1. Bandung: Alumni.

21. Khamisa, N., Peltzer, K., Ilic, D., \& Oldenburg, B. (2017). Effect of personal and work stress on Burnout, Job Satisfaction, and General health of Hospital Nurses in South Africa. Health Sa Gesondheid, 22, 252-258, D0I: doi.org/10.1016/j.hsag.2016.10.001

22. Khotimah, Khusnul. (2010). Hubungan Antara Persepsi Terhadap Lingkungan Kerja Psikologis dengan Burnout Pada Perawat RSU Budi Rahayu Pekalongan. Skripsi Universitas Diponegoro Semarang.

23. Lazarus, R.S \& Folkman, S. (1984). Stress Appraisal And Coping. New York: Spinger Publishing Company. Inc.

24. M Soelton, P Amaelia, H Prasetyo. 2020. Dealing with Job Insecurity, Work Stress, and Family Conflict of Employees.

25. 4th International Conference on Management, Economics and Business (ICMEB 2019). 2020/2 (167-174). atlantispress.com

26. M Soelton, D Amalia, N Noermijati, B Wahyudiono. 2020. Self-Esteem: The Levels of Religiosity in Job Insecurity and Stress in Government Company. 4th International Conference on Management, Economics and Business (ICMEB 2019). 2020/2 (302-310). atlantis-press.com

27. F Rohman, YB Abadi, M Soelton, N Prasetyo, ET Saratian. 2020. The Effect of Environmentally Friendly Paper Toward Purchasing Intention. 4th International Conference on Management, Economics and Business (ICMEB 2019). 2020/2 (120-126). atlantis-press.com 
Soelton, M., Visano, N. A., Aulia, I. N., Rohman. F., Abadi. Y. B., \& Adelia, D. (2020) Factors That Affect The Masinical Productivity In The Indonesian Railway Industry. Archives of Business Research, 8(5). 49-62.

28. M Soelton, D Hardianti, S Kuncoro, J Jumadi. 2020. Factors Affecting Burnout in Manufacturing Industries. 4th International Conference on Management, Economics and Business (ICMEB 2019). 2020/2 (46-52). atlantispress.com

29. M Mugiono, BH Purwoko, M Soelton, R Yuvitasari. 2020. Recognizing How the Job Involvement, Burnout, and Self-Efficacy Work Influences the Work Stress at International Hospitals. 4th International Conference on Management, Economics and Business (ICMEB 2019). 2020/2 (264-270). atlantis-press.com

30. M Soelton, PA Lestari, H Arief, RL Putra. 2020. The Effect of Role Conflict and Burnout Toward Turnover Intention at Software Industries, Work Stress as Moderating Variables. 4th International Conference on Management, Economics and Business (ICMEB 2019). 2020/2 (185-190). atlantis-press.com

31. DF Suzabar, M Soelton, M Umar, J Triwulan. 2020. Recognizing How the Time Demands of Work Influences the Turnover Intention in Banking Industry. 4th International Conference on Management, Economics and Business (ICMEB 2019). 2020/2 (40-45). atlantis-press.com

32. A Nanda, M Soelton, S Luiza, ETP Saratian. 2020. The Effect of Psychological Work Environment and Work Loads on Turnover Interest, Work Stress as an Intervening Variable. 4th International Conference on Management, Economics and Business (ICMEB 2019). 2020/2 (225-231). atlantis-press.com

33. Mangkunegara, A. A. Anwar Prabu (2016). Manajemen Sumber Daya Manusia Perusahaan. Bandung: PT. Remaja Rosdakarya.

34. Martalia, Sarah (2019). Pengaruh Lingkungan, Motivasi dan Keterampilan Kerja terhadap Produktivitas kerja Studi kasus pada PT. Monang Sianipar Abadi Jakarta Unit Minangkabau. Skripsi Universitas Mercu Buana.

35. Maslach, C., \& Leiter, M. (2015). Its Time To Take Action On Burnout. Bunrout Research Articel 2. DOI: 10.1016/j.burn.2015.05.002.

36. Merdiana. (2005). Manajemen Produksi. Jakarta: Penerbit Badan Penerbit IPWI.

37. Moekijat. (2010). Manajemen Sumber Daya Manusia. Bandung: Mandar Maju.

38. Natalia, K., \& Supramono. (2011). Pengaruh Budaya Organisasi, Self-Efficacy dan Strategi Coping Proaktif Terhadap Burnout. Jurnal Ekonomi dan Bisnis, 16 (1), 35-44.

39. Nayeri, N., D., Negaradeh, R., Vaismoradi, M., Ahmadi, F., \& Faghihzadeh, S. (2009). Burnout and Productivity Among Irian Nurses. Nursing and Health Sciences, 11, 263-270. DOI: 10.1111/j.1442-2018.2009.00449.x

40. Nitisemito, A.S. (2011). Manajemen Personalia. Jakarta: Ghalia Indonesia.

41. M Nurhayati, A Thoyib, DW Irawanto, 2019. Impersonal Trust and Perceived Organizational Politics on Organizational Commitment. European Research Studies Journal 21 (3), 391-403 | vol: | issue : | 2018

42. M Nurhayatia, A Thoyib, N Noermijati, 2017. The Role of Political Skills for Organizational Commitment. International Journal of Economic Perspectives 11 (4), 493-498 | vol: | issue : | 2017

43. Nurjayanti, Arnita. (2011). Hubungan Antara Self Efficacy dengan Produktivitas Kerja Pegawai Batik. Skripsi Universitas Muhammadiyah Surakarta..

44. Prestiana, N.D.I., \& Purbandini, D. (2012). Hubungan antara Efikasi Diri (Self efficacy) dan Stres Kerja dengan Kejenuhan Kerja (Burnout) Pada Perawat IGD dan ICU RSUD Kota Bekasi. Jurnal Soul, 5 (2), 1-14.

45. Priansa, D. J. (2017). Manajemen Kinerja Kepegawaian, Bandung: CV Pustaka Setia.

46. Rivai, V. \& Deddy, M. (2010). Kepemimpinan dan Perilaku Organisasi. Jakarta: Rajawali Pers.

47. Robbins, Stephen P. \& Timothy A. Judge. (2014). Perilaku Organisasi. Jakarta: Salemba Empat

48. Rosyid, Haryanto. (1996). Burnout: Penghambat Produktivitas Yang Perlu Dicermati. Bulletin Psikologi, 4 (1).

49. Saefullah., Listyawati., \& Amalia, A. (2017). Pengaruh Beban Kerja dan Stres Kerja terhadap Produktivitas Kerja Karyawan. AKADEMIKA, (15) 2, 117-122.

50. Santrock, \& John, W. (2003). Adolescence. Jakarta: Erlangga. 
51. Samsudin, Salidi. (2010). Manajemen Sumber Daya Manusia. Bandung: Pustaka Setia.

52. Saranani, F. (2013). The Effect of Work Stress on Productivity with Mediation Locus of Control and Social Support. European Journal of Social Sciences, 40(3), 432-440.

53. Satriyo, M. \& Survival (2014). Stres Kerja Terhadap Burnout Serta Impilkasinya Terhadap Kinerja (Studi Terhadap Dosen Pada Universitas Widyagama Malang). Jurnal Manajemen dan Akuntansi, 3 (2), $52-63$.

54. Schawarzer, R. \& Hallum, S. (2008). Perceived Teacher Self Efficacy as a Predictor of Job Stress and Burnout, 57, 152-171. DOI: $10.1111 /$ j.1464-0597.2008.00359.x

55. Sedarmayanti. (2011). Manajemen Sumber Daya Manusia, Reformasi Birokrasi dan Manajemen Pegawai Negeri Sipil, Edisi Lima, Bandung: PT. Refika Aditama.

56. Sihotang Novelina, \& I. (2004). Burnout Pada Karyawan Ditinjau Dari Persepsi Terhadap Lingkungan Kerja Psikologis dan Jenis Kelamin. Jurnal PSYCHE, 1 (1), 10-17.

57. Sinungan, Muchdarsyah. (2014). Produktivitas: Apa dan Bagaimana. Jakarta: Bumi Aksara.

58. Skaalvik, M.E., \& Skaalvik, S. (2010). Teacher Self Efficacy and Teacher Burnout. Teaching and Teacher Education, 26, 1059-1069. DOI: 10.1016/j.tate.2009.11.001

59. Soelton, M., Nugrahati, T., Setiawan, M., Rochman, F., \& Pratama, A. (2019). Gender: Stress Levels on Performance in Modern Industry. Archives of Business Research, 7 (2), 72-81, DOI: 10.14738/abr.72.6131.

60. Soelton, M., Umar, M. (2018). Recognizing How The Time Demands of Work Influences the Turn Over Intention in Banking Industry. European Journal of Business and Management (EJBM), 12 (19)

61. Soelton, M. (2018). How Culture, Training Standard and Discipline on the Employee Performance Affect Hotel Management. European Research Studies Journal, 21(4), 378-385.

62. Soelton, M., \& Nugrahati, T. (2018). How Complaining Behaviors Effect on Coping Stress and Anxiety. International Journal of Saudi Journal of Business and Management Studies (SJBMS), 3(6), 623-628.

63. Soelton, M., \& Oktapriatna, N. (2018). How Complaining Behaviors Effect on Performance in Government Industries?. International Journal of Saudi Journal of Business and Management Studies (SJBMS), 3(6), $623-628$.

64. Soelton, M., \& Rakasidhi, J. (2018). How to Implementation Organization Citizenship Behaviors with performance on Accident insurance service. European Journal of Business and Management (EJBM), 10(15), 10-16.

65. Soelton, M., Pebriani, P., Umar, M., Triwulan, J., \& Wilantara, J. How transformational leadership, communication, and workload on the employee performance affect shoes industries. South East Asia Journal of Contemporary Business, Economics and Law, Vol. 17, Issue 5(December) ISSN 2289-1560

66. Soelton, M., Nugrahati, T., Setiawan, M., Rohman, F., \& Pratama, A. (2019). Gender: Stress Levels On Performance In Modern Industry. Archives of Business Research, 7(2).

67. Stoner, S., James, A.F., \& Charles, W. (2013). Pengantar Manajemen. Jakarta: PT. Indeks Gramedia Grup.

68. Sugiyono. (2013). Metode Penelitian Bisnis. Bandung: Alfabeta

69. Sutrisno, E. (2009). Manajemen Sumber Daya Manusia, Edisi Pertama, Jakarta: Kencana Prenada Media Group.

70. Syamsu, N.N., Soelton, M., Nanda, A., Putra, R.L., \& Pebriani, P. (2019). Bagaimanakah Konflik Peran dan Beban Kerja Mempengaruhi Kinerja Karyawan dengan Burnout Sebagai Variabel Intervening. Jurnal Ilmiah Manajemen Bisnis, 5 (1).

71. Triyoga, A., \& Maharani, P.A. (2012). Job Burnout With Performance By Nurses In Nursing Care Provision. Jurnal Penelitian Stikes RS Baptis Kediri., 5 (2), 167-178.

72. Wang, H., Hall, C.N., \& Rahimi, S. (2015). Self Efficacy and Casual Attributions in Teachers: Effects on Burnout, Job Satisfaction, Illness, and Quitting Intentions. Teaching and Teacher Education, 47, 120-130, DOI: dx.doi.org/10.1016/j.tate.2014.12.005

73. Wartono, Tri. (2013). Pengaruh Stres Kerja Terhadap Kinerja Karyawan (Studi Pada Karyawan Majalah Mother and Baby). Jurnal Ilmiah Prodi Manajemen Universitas Pamulang, 4 (2), 41-55. 
Soelton, M., Visano, N. A., Aulia, I. N., Rohman. F., Abadi. Y. B., \& Adelia, D. (2020) Factors That Affect The Masinical Productivity In The Indonesian Railway Industry. Archives of Business Research, 8(5). 49-62.

74. Wibowo. (2014). Perilaku Dalam Organisasi. Jakarta: Rajawali Pers.

75. Widowati, Retno. (2016). Motivasi dan Lingkungan Kerja Terhadap Produktivitas Kerja Karyawan Politeknik LP3I Jakarta. Jurnal Lentera Bisnis, 5 (2), 104 - 125.

76. Wirawan. (2012). Menghadapi Stres dan Depresi: Seni Menikmati Hidup Agar Selalu Bahagia. Platinum. Jakarta.

77. Woo, H., Park, S., \& Kim, H. (2017). Job Satisfaction as a Moderator on the Between Burnout and Scholary Productivity Among Conselling Faculty In The U.S. Asia Pacific Education Review. DOI: doi.org/10.1007/s12564017-9506-5.

78. Yana, Dewi. (2015). Stres Kerja pada Perawat Instalasi Gawat Darurat di RSUD Pasar Rebo Tahun 2014. Jurnal Administrasi Kebijakan Kesehatan, 1 (2), 107-115.

79. Yu, X., Wang, P., Zhai, X., Dai, H., \& Yang, Q. (2015). The Effect of Work Stress on Job Burnout Among Teachers: The Mediating Role of Self-Efficacy. Social Indicator Research, 122, 701-708, DOI: 10.1007/s11205-014-0716-5. 